\title{
Territorial borders, toleration and the English School
}

\author{
JOHN WILLIAMS*
}

\begin{abstract}
This article offers an assessment of the ethical status of territorial borders, arguing for a partial defence of their role in international relations. Utilising the English School as one way such a defence has been developed, it assesses pluralist and solidarist arguments, suggesting both are flawed. The article develops a notion of territorial borders as contributing to the value of tolerating difference in international relations, and that this is an ethically desirable thing to do. It doing so it utilises the political theory of Hannah Arendt as an alternative to more common, if usually implicit, liberal understandings.
\end{abstract}

\section{Introduction}

Some constitutive rules, like exclusive territoriality, are so deeply sedimented or reified that actors no longer think of them as rules at all. ${ }^{1}$

Imagining international relations without territorial borders is difficult. As Ruggie suggests, in relation to establishing exclusive ownership of territory, territorial borders are fundamental to the way we think about international relations and vital to shaping political practice. 'Constitutive rules are the institutional foundation of all social life. No consciously organized realm of human activity is imaginable without them, including international politics. ${ }^{2}$ International relations would not be international relations without territorial borders.

Should we perpetuate this situation? Should we obey the constitutive rules wherein territorial borders play such an important role? Are they the result of inertia after centuries of 'sedimentation'? Do practical, pragmatic politics make challenging territorial borders too risky or costly? Are there ethical reasons for recognising and respecting territorial borders and their associated rules?

Answering these questions, let alone providing a full account of the importance of territorial borders, is an enormous task. This article offers one small part of an answer by defending ethical reasons for respecting territorial borders, suggesting they can contribute to tolerating diversity in international relations, and that tolerating diversity is ethically desirable.

The territorial borders discussed here are those delimiting exclusive territoriality, highlighted by Ruggie. The article is about the territorial borders of sovereign states.

\footnotetext{
* I am grateful to Andrew Schaap, the Review's referees, Nigel Dower, David Blaney, and John Macmillan for their comments on earlier versions of this article.

1 John Gerard Ruggie, 'What Makes the World Hang Together? Neo-Utilitarianism and the Social Constructivist Challenge', International Organization, 52:4 (1998), p. 873.

2 Ruggie, 'What Makes the World Hang Together?', p. 873.
} 
This does not exhaust the range of borders in international relations. However, territorial borders are fundamentally constitutive of the international relations as interstate relations that still provides the bedrock, backdrop and starting point for much of the discipline's work, including this piece.

The article considers one important and self-consciously ethical justification of territorial borders - the idea of an 'international society' associated with the 'English School' of international relations theory. It assesses the problems this approach faces stemming from the greater prominence of human rights and similar issues, and recent efforts to recast English School theory methodologically utilising constructivism. This has produced calls for a less state-based approach to understanding international society, with more room and a louder voice for non-state actors, especially individuals and those communities not institutionalised in or in control of sovereign states. This is contrasted with a 'classical pluralist' approach that sees borders as essential to order in an anarchic world of diverse states, generating a need for toleration in the form of an international modus vivendi.

The article argues that the English School demonstrates a broadly liberal approach to the idea of toleration in its understanding of how states address the absence of recognised and agreed universal values. Utilising the work of the leading political theorist of toleration, Susan Mendus, suggests this liberal approach is inadequate.

Finally, the article offers a richer approach to toleration, rooted in the political theory of Hannah Arendt, developing an amended and revived pluralist ethical agenda. This approach includes classical English School arguments about borders being essential to create and maintain order amongst states in conditions of anarchy and, in particular, diversity. However, rather than this being a somewhat regrettable necessity, the article asserts a more explicit and positive ethical assessment of diversity and the role played by territorial borders. It puts diversity at the centre of the human condition arguing territorial borders can play a part in protecting the diversity that is an essential part of a progressive politics that gives more space and a greater voice to individual and non-state groups. Diversity needs to be tolerated in the sense of being positively valued and engaged with as part of an open politics, rather than reluctantly forborne as a result of circumstance or necessity. The article defends pluralism and a pluralist English School theory of the states-system via a more far-reaching concept of toleration, a concept that challenges classical pluralism's conservative, statist focus to argue for a place for territorial borders in an open, diverse and tolerant international politics.

\section{International society, territorial borders and plurality ${ }^{3}$}

Political geographers have criticised a lack of conceptual thinking about territory in international relations, arguing the approach has been static, taken for granted and overly concerned with exclusion and exclusivity. ${ }^{4}$ The English School ${ }^{5}$ is arguably

\footnotetext{
3 'Plurality' and 'pluralism' refer to different ethical and normative schemas amongst states. 'Diversity' and 'diverse' refer to such differences amongst individuals and non-state communities.

4 For example, John Agnew and Stuart Corbridge, Mastering Space: Hegemony, Territory and Political Economy (London: Routledge, 1995).

5 English School is used to refer to the body of theory, international society to the political situation most closely associated with this theory.
} 
guilty of this static and exclusivist approach. 'From the perspective of any particular state what it hopes to gain chiefly from participation in the society of states is recognition of its independence of outside authority, and in particular its supreme jurisdiction over its subjects and territory' ${ }^{6}$ Borders establish and define sovereign ownership of territory and jurisdictional authority. State territory ought to be inviolable, whether by secession, irredentism or annexation, or by coercive interference in the state's affairs. These principles - territorial integrity and non-intervention - are vital goals states hope to fulfil through membership of the states-system. Both presuppose borders as delimiters of sovereign territory, inextricable from the foundational principle of sovereignty. Territorial borders in this sense are politicojuridical, rather than sociological, although the article suggests that maintaining such a clear distinction is neither as easy nor as necessary as sometimes argued. ${ }^{7}$

However, the protection borders grant states is conditional. 'International society has in fact treated the preservation of the independence of particular states as a goal that is subordinate to the preservation of the society of states itself'. ${ }^{8}$ However, whilst true of the particular borders of particular states the idea of whichever states are in existence at any time having territorial borders remains vital to the fundamental perpetuation of international society. ${ }^{9}$

The English School thus fits with Ruggie's assertion about borders as reified constitutive rules. Adam Watson argues, 'No system has existed without rules and conventions of some kind, and it is difficult to see how one could'. ${ }^{10}$ Robert Jackson often appeals to 'political reality' in defence of international society as a normative framework, a reality meaningless, indeed non-existent, without a specific understanding of territorial borders. ${ }^{11}$

If territorial borders are fundamental to international order because they create and maintain an international society, why is there a need for order? Bull argues order is, '. . . a pattern of activity that sustains elementary, primary or universal goals of social life'. ${ }^{12}$ Without order life would not be worth living. The main challenge to international order is anarchy, although Bull is sceptical about anarchy inevitably reproducing amongst states a Hobbesian state of nature. ${ }^{13}$ Nevertheless, exploring the states-system's development in mitigating the effects of anarchy is a principal concern of the English School. ${ }^{14}$ Territorial borders are crucial to basic

${ }^{6}$ Hedley Bull, The Anarchical Society: a Study of Order in World Politics (London: Macmillan, 1977), p. 17.

7 Robert Jackson, The Global Covenant: Human Conduct in a World of States (Oxford: Oxford University Press, 2000), pp. 316-35.

8 Bull, Anarchical Society, p. 17.

9 Ibid., p. 16.

10 Adam Watson, The Evolution of International Society: a Comparative Historical Analysis (London: Routledge, 1992), p. 312.

11 Jackson, Global Covenant, pp. 377-99.

12 Bull, Anarchical Society, p. 5.

13 Ibid., pp. 46-51. For a critique of 'Hobbesian' anarchy, see Charles R. Beitz, Political Theory and International Relations (Princeton, NJ: Princeton University Press, 1979), pp. 11-66.

14 Theoretical accounts include Bull, Anarchical Society; Martin Wight, Systems of States (Leicester: Leicester University Press, 1977); Martin Wight (edited by Brian Porter and Gabrielle Wight), International Theory: the Three Traditions (Leicester: Leicester University Press, 1991). Historical and regional accounts include Hedley Bull and Adam Watson (eds.), The Expansion of International Society (Oxford: Clarendon Press, 1984); Watson, The Evolution of International Society. Also Tim Dunne, Inventing International Society: a History of the 'English School' (Houndmills: Macmillan, 1998). 
goals of system perpetuation, state independence, limits on violence, sanctity of agreement and stability of possession. These contribute to maintaining order and preventing challenges to the system such as a successful drive to universal empire.

Whilst this addresses the 'supreme jurisdiction over . . . territory', where does this leave the 'subjects' over which Bull asserts states seek supreme jurisdiction? English School theory considers the relationship between domestic political developments and the states-system, and vice versa. For example, Martin Wight recognised how nationalism and self-determination had implications for recognition. ${ }^{15}$ The 'subjects' of territorially delimited states have a role to play in this account.

Recognising the historically changing nature of states, including the political aspirations and expectations of their inhabitants, hints at problems faced by the English School on the issue of borders. ${ }^{16}$ Popular sovereignty emphasises that many governments are poor representatives of popular political will and underpins claims of secession and irredentism. State coercion and repression often meet these pressures for change and reform. We need to navigate between protecting constitutive rules of the system linked to inviolable territorial borders and responding to popular pressure for change. How much 'domestic' injustice can be borne in the name of protecting a system of 'international' order? ${ }^{17}$ Jackson's defence of the 'classical' approach to theorising international society stresses the difficult and often agonising decisions political and military leaders may face as a result. ${ }^{18}$

Ethical diversity and the role of territorial borders as delimiters of political communities exacerbates the problem in international society. Such communities are not just a group of people bound together by collective subjection to sovereign authority. They may share distinctive views of themselves and the world in contrast to other such communities. For classical pluralists in particular this communal ethical diversity adds to the need for order in international politics and thus the need to respect territorial borders. ${ }^{19}$ Such 'national' identity, idealised in the nation-state, is only one collective identity. However, it is most important in this discussion and highlights the problem of maintaining a strict distinction between juridical and sociological conceptualisations of borders in international society.

It also raises the issue of borders as mechanisms for toleration in international society. Territorial borders and associated rules of sovereignty, territorial integrity and non-intervention have helped states co-exist in an orderly fashion and with less violence and chaos than might otherwise have ensued. International society is partly characterised by an agreement to disagree on the correct way to order domestic society, economy, politics and justice, given the absence of general agreement on principles governing such arrangements. This claim to establish toleration of diversity is important to classical pluralism and key to its understanding of the positive

15 Wight, Systems of States, especially ch. 6.

16 For analysis of the way changing state forms affect the states-system, with some faint praise for the English School, see Mlada Bukovansky, 'The Altered State and the State of Nature - the French Revolution and International Politics', Review of International Studies, 25:2 (1999).

17 John Vincent, Human Rights and International Relations (Cambridge: Cambridge University Press, 1986). Hedley Bull, 'Order vs. Justice in International Society', Political Studies, 19:3 (1971). Hedley Bull, Justice in International Relations (Ontario: University of Waterloo Press, 1984).

18 Jackson, Global Covenant, section 2.

19 Michael Walzer, 'The Rights of Political Communities' and 'The Moral Standing of States: a Response to Four Critics', in Charles R. Beitz et al. (eds.), International Ethics (Princeton, NJ: Princeton University Press, 1985). 
role of territorial borders. However, it rests on a flawed notion of toleration and establishes a system of tolerance that is too narrowly focused on states and too broad in the leeway it grants states to practice domestic intolerance.

The double problem of anarchy and diversity contributes to the 'pluralist' versus 'solidarist' dispute within the English School. For my purposes this tension is crucially about how far diversity precludes universal ethical principles operating in international society and when such principles might override norms, including nonintervention, central to order in anarchy.

This tension is evident in Bull's writings: '. . . if any value attaches to order in world politics, it is order among all mankind which we must treat as being of primary value, not order within the society of states. If international order does have value, this can only be because it is instrumental to the goal of order in human society as a whole'. ${ }^{20}$ This reflects a cosmopolitan ethical schema wherein individuals are, '. . . permanent and indestructible . . . ${ }^{21}$ '[T]he rights and benefits to which justice has to be done in the international community are not simply those of states and nations, but those of individual persons throughout the world as a whole. ... [T] he idea of the rights and duties of the individual person has come to have a place, albeit an insecure one, and it is our responsibility to extend it'. ${ }^{22}$

However, political realities make this cosmopolitanism impractical: 'This is the moment for international relations . . ', ${ }^{23}$ reflecting the absence of a world society of individuals and 'the reality of [an] international society' of states. ${ }^{24}$ Borders constitute international society as pluralist, reinforcing artificial, but very important, national identities, political differences and disputes. Borders close off international politics from widespread participation by establishing international society as a substantially separate space of politics populated by states' representatives, rather than people more generally.

Pluralist thought goes further than this plurality of states' dominant domestic ethical frameworks, though, because of Bull's scepticism about the particular nature of ostensibly universal ethical schemes. ${ }^{25}$. . [T]here is no consensus in the world behind the program [sic] of Western solidarists ... for "transcending the statessystem". '26 Bull's defence of pluralism emphasises its inescapability in state practice and the need for prudence, sensitivity and humility about Western cosmopolitanism and its potential dangers. ${ }^{27}$ However, there remains, '. . . the need that we recognize to inculcate a greater sense of unity in human society, [and] that it is upon the statessystem that our hopes . . ., at least in the short run, must depend.' ${ }^{28}$ Prudence is the principal political virtue in Jackson's defence of pluralism, including in circumstances of Western hubris about its triumph or superiority. ${ }^{29}$

20 Bull, Anarchical Society, p. 22.

21 Ibid., p. 22.

22 Bull, Justice in International Relations, p. 12.

23 Bull, Anarchical Society, p. 22.

24 Ibid., p. 40. For discussion see Nicholas J. Wheeler and Timothy Dunne, 'Hedley Bull's Pluralism of the Intellect and Solidarism of the Will', International Affairs, 72:1 (1996).

25 For example, Bull, Justice in International Relations.

26 Hedley Bull, 'The State's Positive Role in World Affairs', Dadalus, 108:4 (1979), p. 120.

27 Bull, 'Positive Role', pp. 122-3. Bull, Justice in International Relations, pp. 10-11.

28 Bull, 'Positive Role', p. 120.

29 On prudence see Jackson, Global Covenant, p. 21 and passim. On the hubris of the West, see pp. $366-70$. 
However, neither Bull or Jackson provide a positive defence of ethical diversity in contemporary international society. Their pluralism is importantly the result of circumstance and fear about potential disorder stemming from a more solidarist line. ${ }^{30}$ Territorial borders contribute to toleration in a pluralist international society because they help give us reasons to put up with diversity amongst states until this can be overcome.

For Chris Brown classical pluralism is thus a 'second best', and inadequate, theory of international relations. By this he means that it generates an ethic for the world as it is despite recognising the ethical superiority, were it attainable, of a cosmopolitan world based on universal human moral equivalency. ${ }^{31}$ Bull and Jackson would presumably demur from this characterisation, but the charge carries some force. Jackson, for example, side-steps Brown's claim. 'The thrust of the argument . . rejects the illusory belief that the conduct of statespeople can be judged by applying the theories of moral philosophers' ${ }^{32}$ Instead the actions of statespeople can only be judged by their own standards, rendering them immune to vast swathes of ethical critique. This also very substantially narrows Wight's channels whereby domestic politics can influence international society, something the article will try to reverse.

For Jackson, change and development comes exclusively from within the traditions of conduct in international society, hence the irrelevance of moral philosophy and other normative discourses. For Jackson, toleration can only be about putting up with diversity amongst territorially defined and bordered states because these states define the reality of the system from within which the problem arises and from within whose limited practices any solution must appear. However, as Bull noted, system perpetuation is at the heart of classical pluralism's normative vision, consigning us to more of the same until diplomatic practice somehow overcomes this problem or the system collapses.

Nevertheless, some contemporary English School theory has taken up Brown's charge. Explicitly constructivist approaches, as developed by Dunne and Wheeler for example, champion solidarism, asserting international society's potential contribution to a cosmopolitan ethical order. ${ }^{33}$ Similarly, Linklater utilises Habermasian Critical Theory to situate international society within a more cosmopolitan, and ethically superior, worldview. ${ }^{34}$ Constructivist and Critical approaches reopen the potential for change from below in international society and stress the connection to a putative cosmopolitan world society. They emphasise how Bull's appeal to 'the reality of international society' need not separate ethical aspirations, such as a cosmopolitan human rights, from international relations theory. The constructivist view of the constitutive rules of international relations as being mutable ideational structures opens features such as anarchy to far reaching ethical, and other, questioning. ${ }^{35}$

30 Bull, Justice in International Relations, pp. 12-18. Jackson, Global Covenant, ch. 6.

31 Chris Brown, 'International Theory and International Society: the Viability of "the Middle Way", Review of International Studies, 21:2 (1995).

32 Jackson, Global Covenant, p. 130.

33 Timothy Dunne, 'The Social Construction of International Society', European Journal of International Relations, 1:3 (1995). Nicholas J. Wheeler, Saving Strangers: Humanitarian Intervention and International Society (Oxford: Oxford University Press, 2000), ch. 1 and 2.

34 Andrew Linklater, The Transformation of Political Community: Ethical Foundations of a PostWestphalian Era (Cambridge: Polity, 1998).

35 For example, Alexander Wendt, Social Theory of International Relations (Cambridge: Cambridge University Press, 1999); Emanuel Adler, 'Seizing the Middle Ground: Constructivism in World Politics', European Journal of International Relations, 3:3 (1997). 
This problematises anarchy as an essential and inescapable condition of contemporary world politics, with far-reaching ethical consequences. If 'anarchy is what states make of it' and the 'facts' of international politics are inseparable from the 'values' inherent in a theory of international politics which orders and prioritises facts we need a more explicit theory of the ethics of an anarchical structure. Wheeler's survey of such efforts suggests this is difficult. ${ }^{36}$ The question of why we should condone morally despicable behaviour, such as torture and massacre, in the name of respecting territorial borders becomes almost unanswerable.

Jackson's unsatisfactory closure of the debate to anything other than the existing standards that generate the problem in the first place ensures its perpetuation. $\mathrm{He}$ emphasises statespeople as doing 'real' international relations, placing commentators and academics in subservient positions, able only to try and imagine themselves into the shoes of statespeople, becoming as hidebound as they by an excessively conservative portrayal of international society. ${ }^{37}$ As it is statespeople who have power they must absorb our attention, he argues, making it unnecessary, even damaging, to consider the world from the viewpoint of the victims of such power. ${ }^{38}$ Jackson's teleological portrayal of history leads us progressively to the present international society that is not only the way the world works but also the only way it could. Each new accretion of law, custom, case and diplomatic practice edges international society slowly forward within its cocoon of separateness from other political and social practice. ${ }^{39}$ It is international society as Gormenghast.

The pluralist strand of English School theory is rendered incapable of finding new and better ways of addressing the dilemmas and agonising decisions Jackson urges sensitivity towards. Rather than condemning statespeople to more of the same by denying them any tools other than those already available, pluralism ought, as the constructivist solidarists are doing, to look beyond diplomatic tradition, custom and practice. International relations ought not, indeed cannot, separate itself off from the rest of human conduct and the insights within.

For solidarists seeking to expand universal ethics in international society, anarchy and diversity are complicating factors, barriers to the recognition of a cosmopolitan truth about human beings. These complications are linked to territorial borders via national self-determination and the idealisation of the state as the manifestation of a distinctive community whose shared history, culture and traditions render it at least partially inexplicable to outsiders who should not attempt to interfere in its affairs. ${ }^{40}$ This is backed by appeals to the constitutive rules of international society, via the doctrine of non-intervention, rooted in the overriding duty of states to maintain their own existence via maintaining the existence of international society itself.

A 'constructivised' English School theory struggles to produce an ethical defence of the states-system. It is committed to territorial borders as essential constitutive rules without which the states-system cannot exist as an international society. However, these rules undermine, even deny, the existence of an essential human

36 Nicholas J. Wheeler, 'Guardian Angel or Global Gangster: a Review of the Ethical Claims of International Society', Political Studies, 44:1 (1996), especially pp. 124-7.

37 Jackson, Global Covenant, pp. 85-91.

38 Ibid., p. 134.

39 Ibid., Section 1.

40 Walzer, 'Moral Standing of States'. 
moral equivalency and repress the voice of the victim in international relations. ${ }^{41}$ The prominence of human rights and humanitarian intervention in this work points to the recognition of this problem and a determination to address it. Whilst not an article about humanitarian intervention per se, being a more general consideration of territorial borders, some preliminary thoughts are offered later on how the revived pluralist agenda the article outlines contributes to debates about humanitarian intervention.

Moving the burden of supporting territorial borders away from anarchy and towards the need for order in conditions of ethical diversity, and particularly the toleration of such diversity as being ethically desirable, ameliorates the problem of imposing, or being seen to impose, a single and specific ethical schema. Formulating this defence of diversity needs to avoid placing such emphasis on the specific circumstances of international society, limiting it to the level of the state and making its defence reliant upon isolating the nature and character of international politics from that of human life more generally. A more explicit, richer and more positive defence of toleration than either Bull or Jackson offers can reinvigorate the pluralist wing of the English School.

However, this requires a conceptualisation of toleration different from the immediately obvious one, rooted in liberal political thought. A discussion of liberal approaches to toleration remains useful because it throws light on weaknesses in both classical and constructivist English School theory.

\section{The concept of toleration}

Toleration is demanding, it requires us, '. . . to practice tolerance even when it is troublesome and painful to do so'. ${ }^{42}$ Toleration is about accepting the validity of things we find distasteful, even things we find morally abhorrent. ${ }^{43}$ Toleration is thus often linked with liberty and a liberal view of politics. However, this may not be a wholly satisfactory position.

Toleration as a specifically liberal virtue is nevertheless a common idea with some apparent parallels with the English School. ${ }^{44}$ Indeed, Jackson specifically identifies his version of pluralism with a liberal 'forbearance and toleration' ${ }^{45}$ John Locke and J.S. Mill offer principal sources for liberal approaches to toleration, elements of both are discernible in English School thinking. ${ }^{46}$ This section will consider how this relates to classical pluralism first, before moving to its role in contemporary solidarism.

Locke advocates religious toleration because coercing genuine faith is impossible and therefore futile. Religious intolerance is only justifiable where religious practices

${ }^{41}$ For example, Wheeler, Saving Strangers, p. 38.

42 Glenn Tinder, Tolerance: Toward a New Civility (Amherst, MA: University of Massachusetts Press, 1976), p. 8.

${ }_{43}$ Susan Mendus, Toleration and the Limits of Liberalism (Houndmills: Macmillan, 1989), pp. 8-18.

44 Joseph Raz, 'Autonomy, Toleration and the Harm Principle', in Susan Mendus (ed.), Justifying Toleration: Conceptual and Historical Perspectives (Cambridge: Cambridge University Press, 1988), p. 155; Tinder, Tolerance.

45 Jackson, Global Covenant, p. 139.

46 This account of Locke and Mill relies principally on Mendus, Toleration and the Limits of Liberalism, pp. 22-68. 
threaten state security. In such circumstances it is not faith that is being regarded intolerantly, but consequences of actions springing from faith.

And if, peradventure, such were the state of affairs, that the interest of the commonwealth required all slaughter of beasts should be forborn while, in order to the increasing of the stock of cattle, that had been destroyed by some extraordinary murrain; who sees not that the magistrate, in such a case, may forbid all his subjects to kill any calves for any use whatsoever? Only it is to be observed, that in this case the law is not made about a religious, but a political matter: nor is the sacrifice, but the slaughter of calves thereby prohibited. ${ }^{47}$

Locke's clear, simple argument is appealing, and seemingly appropriate to international society by analogy, leaving aside doubts about the empirical accuracy of the impossibility of coercing changes in faith. ${ }^{48}$ Forcibly altering domestic political practices that infringe human rights, for example, is indefensible except in the most extreme cases. Only through winning the arguments can respect for human rights be entrenched in societies that presently reject them.

The extreme circumstances justifying forcible intervention are limited to human rights abuses so serious they threaten the security of states and international society. This chimes with Bull's identification of the perpetuation of the society of states as a fundamental goal that may require the forbearance of injustice. Similar arguments exist in political practice: the United Nations Security Council has used threats to international peace and security to address humanitarian disasters. ${ }^{49}$

Locke's argument appears to have utility as an ethic of toleration for international society. However, it does not generate a positive reason for toleration, or explain why toleration is promoted by the territorial states-system. Locke tolerates religious diversity because forcibly imposing religious uniformity is impossible. Locke has a definite conception of what he wishes universalised-Protestantism-and toleration is only a virtue because circumstances make this impractical. Toleration is prudential or circumstantial rather than a positive virtue. ${ }^{50}$

We have seen that prudence is important in Bull and Jackson's pluralism. They may not share Locke's commitment to a particular view of the good life-both reject advocacy of the superiority of Western liberal democratic capitalism ${ }^{51}$ _ but they would agree there are intolerable forms of political life. This is because they threaten basic structures of order, in this case international society. Political forms rejecting sovereign statehood as the basis for order and coexistence in anarchy and diversity are unlikely to be forborne, let alone tolerated. A Burkeian conservatism on the basis of tradition and custom and out of fear for the fragility of order reinforces this limited toleration. ${ }^{52}$

47 John Horton and Susan Mendus (eds.), John Locke 'A Letter Concerning Toleration' in Focus (London: Routledge, 1991), pp. 36-7.

48 Selina Chen, 'Locke's Political Arguments for Toleration', History of Political Thought, 19:2 (1998), p. 169 .

49 John Williams, 'The Ethical Basis of Humanitarian Intervention, the Security Council and Yugoslavia', International Peacekeeping, 6:2 (1999).

50 Chen, 'Locke's Political Arguments for Toleration' offers a more positive assessment. However, this rests on cosmopolitan assumptions about universal rationality that leaves it open to similar teleological challenges as apply to Mill.

51 Bull, Justice in International Relations. Jackson, Global Covenant, pp. 51-8.

52 I am grateful to an anonymous referee for emphasising Bull's use of Burke. Jackson cites him repeatedly in Global Covenant. 
J.S. Mill seems of more use in constructing a positive liberal argument because he emphasises the virtue of diversity. Mill claims that valuing, even encouraging, diversity in society ensures as many opportunities as possible for progress. Tolerating diversity prevents society slipping into conformity, torpor, conservatism and backwardness. Hearing as many voices and seeing as many alternatives as possible protects the creative spark enabling social progress.

Bull's uncertainty about the superiority of Western ideas and his appeals for sensitivity towards other cultures echoes this kind of reasoning. The pluralism of international society matters because it offers different voices against which we can judge ourselves, interact with and learn from. ${ }^{53}$ This reinforces prudential concerns about the risks of imposing universality.

Mill's enthusiasm for diversity sometimes approaches valuing eccentricity for eccentricity's sake. However, Mill's teleology of progress restricts his tolerance and, ultimately, Bull's too. Unlike Locke, Mill offers only a weak reason why we should tolerate that of which we morally disapprove. ${ }^{54}$ Locke's answer is the impossibility of changing beliefs (although he does not extend such licence to action resulting from such beliefs). Mill's answer is weak because he stresses toleration's purpose being to foster progress and improvements in society. A strong prescriptive element informs Mill's conception of progress - predicated upon the principles of Utilitarian liberalism - meaning that the licence of toleration within society is limited.

Similarly, classical English School pluralists tolerate diversity within states if it does not threaten order in international society by undermining progress in extending the enmeshing web of rules and principles entrenching order amongst states. Jackson's unease over possible extensions to the jus ad bellum sanctioning humanitarian intervention is indicative. ${ }^{55}$ Progress in restricting legitimate causes of war should be tampered with only with extreme caution and a presumption in favour of the status quo. Bull's approving summary of the development of natural law thinking, one of the few positive things he has to say about natural law, and its role in shaping contemporary understandings of problems such as this, also hints at a teleological view of progress in our knowledge and understanding. ${ }^{56}$

The scope of toleration is therefore likely to narrow over time as agreement develops. As Bull notes, 'The future of international society is likely to be determined, among other things, by the preservation and extension of a cosmopolitan culture, embracing both common ideas and common values, and rooted in societies in general as well as in their elites' ${ }^{57}$ The process is the refinement of the rules, norms and principles of behaviour tying states to international society and ensuring those issues and problems deemed to matter in international relations are principally those comprehensible to and manageable within international society. Diversity within states is not extended to, and is significantly limited by, the similarity of states in international society.

Mill's seemingly positive reason for tolerating diversity is more restricted than at first sight. Mill gives us reason to tolerate what we dislike, but not that we morally

53 Bull, Anarchical Society, p. 317.

54 D. D. Raphael, 'The Intolerable', in Mendus (ed.), Justifying Toleration.

55 Jackson, Global Covenant, ch. 10.

56 Hedley Bull, 'Natural Law and International Relations', British Journal of International Studies, 5:2 (1979), pp. 174-5.

57 Bull, Anarchical Society, p. 317. 
condemn because it blocks progress. The inherent vision of the good life within Mill's liberalism - its individualism, belief in the public/private divide, its particular vision of political participation, its utilitarianism - make it inimical to those who do not share this teleological vision of history or have a different ontology of the good life. Classical English School pluralists also have a view of the good life for statesthe global covenant of international society - and a toleration of diversity within its parameters and confined by territorial borders to a specific place, within the sovereign state. Territorial borders thus limit toleration and identify those areas where its licence is greatest and those where it is highly restricted. International society, as Blaney and Inayatullah argue, stems from 'the Westphalian deferral' of the diversity question in international relations. International society does not fully answer or even address the issue of diversity, instead deferring it by limiting it to and containing it within states in ways that are increasingly unstable and that seriously challenge classical pluralism's perspective. ${ }^{58}$

Alternative views of international relations and ethical systems challenging the global covenant pose the greatest test for toleration. A positive ethical defence of territorial borders must deal with the challenge of tolerating that of which we morally disapprove, something which liberalism, on this very short survey, struggles to do as fully as is necessary. ${ }^{59}$ Radical alternative challenges may be accepted for practical and pragmatic reasons, but they are not valued, their heretical opinions protected-we do not tolerate them in the full meaning of the term.

Constructivist solidarism shares an implicitly liberal approach to toleration. Territorial borders are understood differently — as Ruggie's sedimented and reified constitutive rules - but with similar ethical implications. Excavating the sediment and challenging the reification questions the idea of territorial borders as 'givens' or 'brute facts', opening them to ethical enquiry. Utilising constructivism to solidarist ends means borders must be justifiable within an individual-focused ethical agenda. This is difficult whilst they establish exclusive territoriality and associated principles like non-intervention, even in the face of morally abhorrent behaviour as judged against an ideal cosmopolitan standard. ${ }^{60}$

This move importantly sharpens English School theory's critical edge, a goal of contemporary solidarists. It recasts territorial borders' ethical status as either derivative from their contribution to protecting political communities where cosmopolitan ethical standards are fulfilled, or closely approximated; or as circumstantial within a mechanism generating order in the non-ideal conditions of international politics, preventing worse evils arising from enforced ethical homogeneity. What seems certain is that international society remains an ethically 'second best' arrangement of international relations as it relates to the existence and importance of territorial borders.

Toleration becomes restricted to practices that both conform to dominant norms of international society and are reconcilable with certain cosmopolitan standards. States professing such standards should bear some costs in more active pursuit of these ends, tempered by the need to respect and protect order and within limiting

58 David L. Blaney and Naeem Inayatullah, 'The Westphalian Deferral', International Studies Review, 2:2 (2000).

59 Mendus, Toleration and the Limits of Liberalism, pp. 18-21. See also Raphael, 'The Intolerable'.

60 Wheeler, 'Guardian Angel or Global Gangster'. 
domestic political realities. ${ }^{61}$ Sensitivity to pluralistic aspects of international society is necessary, because of its deep sedimentation and the often wide gaps between different conceptions of the good life. This toleration is, though, principally prudential, circumstantial and of derivative ethical significance, mirroring the status of territorial borders. The largely liberal version of solidarism advocated by Wheeler, for example, brings with it a liberal concept of toleration. As we have seen, this struggles to produce a justification for international society and constitutive norms like territorial borders that is explicit and above all positive in its toleration of diversity, including potentially radical diversity from the norms of international society.

\section{A richer concept of toleration}

Prudence, circumstance, the realities of power, anguish and uncertainty about Western values all contribute to an understanding of toleration in classical pluralism that falls victim to the weaknesses of a liberal version of toleration. Contemporary constructivist solidarism does not escape this failure of liberalism to generate an explicit and positive reason to tolerate diversity in the full sense of the term. A richer concept of toleration is necessary. This must be more open to alternative conceptions of the good life, of the ontological status of human beings and of the nature of politics. It needs to address a more diverse international political system and accommodate a wider range of actors. It must also protect what is essential by identifying what is intolerable. Toleration means the positive valuing of and engagement with diversity in ways that are not prejudged or inevitably circumscribed by the system within which we operate or aspire to operate.

This is a very tall order indeed, and this article only outlines how such a project might begin. A stronger concept of toleration needs to deal with radical difference, even in the form of hatred, prejudice and conflict. These are negative forces that ought to be opposed and, if possible, eradicated. However, they are also amongst the most powerful motivations for political action and are prominent in political conduct. Genuine toleration, living and engaging with that we morally disapprove of, needs better ways of understanding and addressing these 'negative' forces in a pluralist international society.

This is where Hannah Arendt comes into play. Arendt's breadth of interests makes other than skimming the surface of her potential contribution to international political theory impossible here. In placing an ethic of toleration at the heart of a pluralist English School this skimming may prove profitable.

Arendt's potential contribution is twofold and distinctive. Firstly is her commitment to diversity as essential to human existence. '. . . [W]e are all the same, that is, human, in such a way that nobody is ever the same as anyone else who ever lived, lives or will live'. ${ }^{62}$ Multiple perspectives are necessary to establish meaning,

61 Nicholas J. Wheeler and Tim Dunne, 'Good International Citizenship: a Third Way for British Foreign Policy?' International Affairs, 74:4 (1998); Bull, Justice in International Relations, p. 13.

62 Hannah Arendt, The Human Condition (Chicago, IL: University of Chicago Press, 1958), p. 8. Jackson quotes this line (The Global Covenant, p. 407) although Arendt's analysis of diversity and its implications for contemporary politics makes little impact on Jackson's thinking. 
meaningfulness and a sense of common reality in human affairs. We cannot understand who we are, as opposed to what we are, outside of the condition of diversity in relation to other human beings. Diversity is neither unfortunate accident of history or byproduct of the states-system. It cannot be deferred, but must be addressed head on.

Diversity's centrality to the human condition and the nature of political action does not preclude potential comprehensibility and understanding amongst individuals and the communities they form. Neither is comprehensibility confined to elite statespeople immune from criticism on other than their own terms. Nor is diversity simple individualism. Individuals are rooted, conditioned creatures via histories and communities that are vital, in both senses of the term. For Arendt, one can only be an individual within a social context, but society does not generate homogeneity. Diversity within communities is at least as great as that between them, but individuals can only recognise their diversity and understand who they are by comparison and engagement with others with whom they share much in common. ${ }^{63}$

Whilst a theorist of the bounded community, Arendt's account of history stresses that ideas of separate, national histories prescribing final destinations are a modern aberration. ${ }^{64}$ However, from this misnomer stem idealised, fixed and permanent boundaries that have to be included in any account of politics. Diversity cannot be transcended, yet its forms are constructed, flexible and conditioned by human action and discourse in innumerable and highly unpredictable ways. Because diversity is inescapable and essential to meaningfulness in human affairs, valuing and protecting it is part of a human politics that relies on interaction within communities. Diversity goes far wider than the plurality of states, although this is important, creating a need to expand connections between the diversity of human beings and their communities, and the institutions, like international society, where diversity is worked out.

For example, reflecting on the Holocaust, Arendt defends her self-recognition as a Jew, an identity inextricable from social and political circumstances contributing to the idea of Jewishness. She contrasts this with appeals to 'humanity' in resisting Nazism, criticising those dismissing specific identity as the source of resistance. 'Those who reject such identifications may feel wonderfully superior to the world ...., but their superiority is . . . the superiority of a more or less well-equipped cloud-cuckoo-land'. ${ }^{65}$

Arendt takes Nazism deeply seriously. It is a force to be understood and engaged with, rather than dismissed out of hand as 'evil' and with no place in politics. Diversity, rooted in individual action and intersubjective construction of individuals within communities, is essential to resisting such projects. In Arendt's account of

63 Arendt uses the terms 'plurality' and 'pluralism' to identify the diversity of individuals and the diversity of communities respectively, both of which are subsumed within my use of 'diversity'. Obviously adopting Arendt's usage here would be impossibly confusing. The distinction is an important one in Arendt's thought and hopefully context and qualification mean some of its force is retained despite being somewhat glossed over.

64 Hannah Arendt, 'The Concept of History', in Hannah Arendt, Between Past and Future (New York: Penguin Books, 1977).

65 Hannah Arendt, 'On Humanity in Dark Times: Thoughts about Lessing', in Hannah Arendt, Men in Dark Times (London: Jonathan Cape, 1970), p. 18. 
Eichmann's trial, the evil of the Holocaust is striking for the banality of so many of its actions, reducing genocide to bureaucratic trivia, dispute and turf fight. The 'banality of evil' cannot be resisted by abstract principles, even ones claiming to be universal, but by everyday, socially rooted resistance based on real lives, identities and communities. ${ }^{66}$ Through the interaction and interplay of these a more genuine universality may be built that can effectively resist totalitarian forces.

Concluding her analysis of totalitarianism, Arendt emphasises its destruction not just of public life, as tyrannies had done in the past, but of private life as well, undermining liberalism's separation of the two. Loneliness - the utter isolation of individuals from their communities under totalitarianism-destroys the human ability to participate in meaningful relationships with others. 'What makes loneliness so unbearable is the loss of one's own self which can be realized in solitude, but confirmed in its identity only by the trusting and trustworthy company of my equals. In this situation, man loses trust in himself as the partner of his thoughts and that elementary confidence in the world which is necessary to make experiences at all'. ${ }^{67}$ Without community and involvement, human identity and the potential for positive action, Arendt's definition of freedom, is unprotected. ${ }^{68}$

The second way Arendt offers a fresh approach stems from emphasising diversity as desirable and the sort of politics this necessitates. Arendt accuses modern, Western, predominantly liberal versions of politics of threatening diversity, homogenising people and undermining their role in a politics potentially able to address these powerful, 'negative' motivations.

Her idea of a genuine, 'worldly' politics distinguishes Arendt from liberalism and its inadequate, if arguably dominant, approach to toleration in international relations. ${ }^{69}$ Arendt believes abstract philosophical bases for virtues, such as toleration, are inadequate, unreflective of a socially constructed reality, the result of human activity and history. ${ }^{70}$ Appeals to universality are possible but only through sharing values via discourse and interaction, rather than through asserting abstract bases. They must come from human action, not from thought alone. ${ }^{71}$ Engaging with the world, by acting within it, is properly political action. It happens within and helps to create and protect a space where others can respond to our actions, creating ties, bonds, communities and also the potential, often stymied, for universality.

Arendt's ideal political world clearly echoes the Athenian agora's politics of direct citizen participation. Well aware this situation cannot be replicated in the modern world, Arendt nevertheless wishes politics would aspire to this spirit. She fears conceptual rigidity and over-concentration on institutions damages the space in-

66 Hannah Arendt, Eichmann in Jerusalem: A Report on the Banality of Evil (London: Faber and Faber, 1963).

67 Hannah Arendt, Origins of Totalitarianism, New edn. with added prefaces (New York: Harcourt Brace Jovanovich, 1973), p. 477.

68 Margaret Canovan, The Political Thought of Hannah Arendt (London: J. M. Dent, 1974), pp. 57-65.

69 Philip Hansen, Hannah Arendt: Politics, History and Citizenship (Cambridge: Polity, 1993), especially pp. 50-88. Canovan, The Political Thought of Hannah Arendt. Bhikhu Parekh, Hannah Arendt and the Search for a New Political Philosophy (London: Macmillan, 1981).

70 For example, her discussion of abstract human rights in Origins of Totalitarianism, pp. 290-302. Also Margaret Canovan, 'Friendship, Truth and Politics: Hannah Arendt and Toleration', in Mendus (ed.), Justifying Toleration, p. 183.

71 See her discussion of the vita activa and the vita contemplativa in Human Condition. 
between individuals and communities as the site of genuine politics. ${ }^{72}$ For Arendt, liberalism is about 'ruling', not politics. ${ }^{73}$ 'Ruling' relieves citizens of the need to actively engage in politics, offering grand schemes concentrated on institutions instead. These will render mass participation unnecessary, giving responsibility for managing these schemes to a small class of professional political craftsmen. Bull and Jackson's stress upon diplomatic culture leaves them vulnerable to this charge.

These two insights enable an alternative approach to toleration that is particularly relevant to international relations. Arendt says, '. . . [T]he world and the people who inhabit it are not the same. The world lies between people, and this in-between ... is today the object of the greatest concern and the most obvious upheaval in all the countries of the globe'. ${ }^{74}$ Engaging openly and fully with the different is the way we engage with ourselves. We need to act in the world, to open ourselves to engagement with those with whom we are familiar and with those with whom we are not.

Turning to Arendt utilises the methodological space opened by constructivism in an unusual way. Rather than seeking to reconceptualise borders as social constructs, down-playing an immutable anarchy to promote a cosmopolitan ethical agenda, Arendt's thought potentially reinvigorates pluralism. By concentrating on and celebrating diversity's centrality to the human condition, rather than limited to the sovereign state level, a pluralistic ethical agenda rooted in the virtue of toleration becomes possible. Arendt does not deny the role of the state, but takes diversity and toleration much further. Arendt offers good reasons to tolerate that which we morally disapprove of and also establishes the ethical significance of territorial borders.

Arendt's political theory of toleration throws new light on pluralism in international society. International society exists in a specific time and place, resulting from historical choices, decisions and reasons. It is a manifestation of human work and action. Arendt's political theory, rooted in the real, lived experiences of human beings, contributes to a constructivist methodological shift. It also places the pluralism of states within the context of the diversity of people and communities. Hopes for universalism must stem from the interaction of individuals rooted in communities central to their identity and to their political motivations. These communities are social constructs, but remain central to the everyday operation of politics, including, and perhaps especially, the politics of hatred and conflict.

Discourse and interaction, not humanity, links people together: 'For the world is not humane just because it is made by human beings, and it does not become humane just because the human voice sounds within it, but only when it has become the object of discourse'. ${ }^{75}$ The space in-between individuals, communities and institutions is where discourse can take place, where identities can meet, generating genuine humanity.

This space in-between is delicate, transitory, ephemeral and intersubjective, contrasting with the resilient, durable, institutionalised view of international society that

72 Arendt, Human Condition, pp. 182-3.

73 Ibid., pp. 28-50. See also Parekh, Hannah Arendt and the Search for a New Political Philosophy, pp. $14-19$.

74 Arendt, 'On Humanity in Dark Times', p. 4.

75 Ibid., p. 24 
for Jackson limits diversity, channelling interaction through the mechanisms of diplomacy, limiting participation in 'real' international politics to a tiny minority. ${ }^{76}$ Arendt reopens the channel between people and international society, enabling the victims of power to be heard, as well as its holders, helping a pluralist English School agenda follow constructivist solidarism's recognition of this need.

An Arendtian approach requires that we return to the world sedimented and reified institutions of international society like territorial borders. We can do this by viewing them as devices for creating a space in-between, rather than treating them as perimeter fences maintained and policed by a small political, diplomatic and military elite. ${ }^{77}$ Borders have served to close off separate worlds. Within states one form of politics takes place, amongst them exists a distinctive political arena where different rules apply. Returning these worlds to a human politics of diversity requires constant questioning of their legitimacy and role, including of the devices that separate them. This occurs via active political involvement through the discourse of real individuals and communities, not by judgement against either abstract absolute standards or an elitist monolith of diplomatic custom and practice. ${ }^{78}$ This reaffirms that the finer details of a politico-juridical, rather than sociological, concept of borders as being the correct one for international relations is undermined by their muddling and mixing in practice and discourse.

Arendt berates the shutting off of political space in modern politics. Classical pluralism does just this ostensibly to protect diversity via a toleration importantly influenced by liberalism. However, Arendt argues that liberalism is 'unworldly' because its distinction between a public, political sphere and a private, apolitical sphere removes vast quantities of human interaction, and hopefully discourse, from consideration as political. ${ }^{79}$ This un-worldliness infects liberalism's approach to toleration. For Arendt, the realm of the political - the realm of the worldly-is infinitely wider and lacks a teleology and moral ontology of individuality such as Mill's. We need to recognise and engage the political aspects of almost all human activity, including that we abhor.

Arendt's toleration is much greater than Mill and other liberals offer. She recognises that hatred, prejudice and conflict matter to individuals and their communities. These forces are significant in a worldly politics. This politics occurs inbetween individuals, their communities and institutions. Genuine discourse involves hearing and considering these voices - not declaring ourselves abstract, individual members of humanity to whom such things are a false consciousness, or irrational, or abhorrent, making consideration unnecessary.

Recognising these negative forces in politics gives us a reason to tolerate themthey are as important to the human experience as commitments to equality, liberty and justice-and their place requires recognition. Understanding, interaction, dialogue and a recognition of human weakness as well as heroism are essential to a worldliness recognising the space in-between human beings, their communities and institutions as the site of politics. This supports pluralist international society as a

76 Jackson argues that 'there are fewer than 20,000 people worldwide who are the primary subjects of international ethics' and of these maybe only 1,000 matter. Global Covenant, p. 134.

77 Jackson uses the border as fence metaphor, The Global Covenant, p. 319.

78 For Arendt's account of politics as action, see Human Condition, pp. 175-247.

79 Hansen, Hannah Arendt, pp. 89-128. 
framework potentially conducive to this kind of politics and its richer version of toleration. Here borders are acceptable but negotiable devices, protecting communities and maintaining a space in-between for discourse: an arena of toleration. Boundaries and borders are inescapable and desirable in a world of diversity and community. Given the current configuration of international politics, territorial borders are inescapable within international society. They may also be desirable if returned to a worldly politics, seeing them as historically contingent devices for creating space in-between some of the communities that characterise the diversity of human life, helping them resist totalising and homogenising projects.

This approach certainly challenges the understanding of borders in English School thinking, classical or constructivist. For Bull and other 'classicals', borders are 'facts' and thus largely unpolitical. They exist and they have to be taken into account. The rules and norms that have built up around them may be political, but international relations will always have to address the issue of borders, even if the exact location of them changes, because without borders there could be no international society, or even an international system. ${ }^{80}$ With constructivism, borders are social facts: important, but deeply political and with serious ethical implications. However, those using constructivism for solidarist purposes portray respecting borders as a prudential or contingent matter, with ethical significance derivative from a wider agenda such as cosmopolitan human rights.

An Arendtian approach sees borders as elements of community and as ways of dividing and dissipating institutional power, accepting the difficulty of maintaining clear definitional lines in an unpredictable and dynamic human political environment. Borders can be vital in resisting 'ruling' and preserving a politics that recognises, cherishes and sustains human diversity. However, this must not repeat the sedimentation and reification of borders - they must remain constantly questioned in response to the unpredictable, ephemeral workings of an intersubjective politics of discourse. ${ }^{81}$ They do, though, act as limits, including helping us to place limits on toleration.

Arendt is deeply concerned with limits in politics, stemming partly from her recognition that civilisation is neither inevitable or even terribly secure from human hubris and the tendency of human-introduced trends to run out of control. ${ }^{82}$ Territorial borders are one form of limitation in politics, the diversity they help protect is another and the idea of toleration is a third. These are far from the only ones, but are the most important in relation to an account of the English School.

Territorial borders as historical, intellectual and social constructions matter because they help divide political authority and military might, fitting with the English School's concerns over universal empire and other totalising projects. Borders establish limits which, if protected and accepted, rob totalitarianism of its dynamism and the political tactic of 'permanent revolution' through which it is able to galvanise support, sweeping away prior political forms. ${ }^{83}$ However, borders remain rooted in the dynamic,

80 Jackson, Global Covenant, pp. 316-35.

81 The struggle to maintain freedom in politics is the central theme of Hannah Arendt, On Revolution (London: Faber and Faber, 1963).

82 Margaret Canovan, 'Hannah Arendt as a Conservative Thinker', in Larry May and Jerome Kohn (eds.), Hannah Arendt: Twenty Years Later (Cambridge, MA: MIT Press, 1996), pp. 14-21.

83 Arendt, Origins of Totalitarianism, pp. 389, 391. 
unpredictable and evolutionary politics of real communities, changing to reflect developments in these communities.

In addition, the rules, norms and principles of the territorially based international society further limit the ability of states to wield the single most important threat to toleration and a worldly politics, violent military might. Territorial borders are mutable constitutive rules, as a constructivist English School must accept, and Arendt offers useful tools for delving into the sediment and challenging the reification of territorial borders by reassessing their roles and purposes, even if she herself offers little direct reflection on this.

Arendt can give us good reasons to tolerate what we morally condemn and can help us place territorial borders back into the political world in a positive way. Tolerating what we morally condemn is right because such things are part of a properly political, worldly, process, engaging people and creating opportunities for discourse to develop. This is what toleration should be about, rather than forbearing things made presently unalterable by circumstances or prudential considerations. The risks are familiar-granting platforms to extremists, racists, bigots and the whole panoply of derogatory language applied to those expressing views we find offensive. This price must be paid, not because we cannot change such people's views, as Locke might argue, but because such views are part of political discourse and dialogue. ${ }^{84}$ Territorial borders can hold open discursive space and a principle like non-intervention can be more than a prudential rule in the face of anarchy. Borders are protective and constitutive of community. For a modified pluralist English School theory, order in diversity ought to be just as important as order under anarchy. If diversity is ethically desirable then this offers a way of avoiding the 'second best' conclusions about international society being a solution fit only for a non-ideal world.

Toleration, however, is not absolute. If we have good reason to be tolerant, this does not mean nothing is intolerable. In effect, the violent refusal to reciprocate toleration is intolerable. Territorial borders can be thought of as ways in which access to political space is partially, if inadequately, pluralised via the division of political authority and military might. This is a two-edged sword, of course. The denial of reciprocal toleration often takes the form of state repression, and when it does, it is at its most severe. Where repression is by state armed force a response by other states is required to restore reciprocal toleration. 'Political equality requires a minimum threshold: that all must have access to the public world'. ${ }^{85}$ Thus Arendt defended Eichmann's right to be heard at his trial, eventually supporting the death penalty because Eichmann denied the Jews' right to exist and participate. ${ }^{86}$ Claims to universal moral status by prevalent political views must be challenged if prevalence is not to result in violently enforced universalism. ${ }^{87}$

84 Arendt was criticised for opposing forcible school integration, arguing this went beyond protecting Constitutional rights and imposed social uniformity. It was thus intolerant. Canovan, 'Friendship, Truth and Politics', pp. 196-7.

85 James Bohman, 'The Moral Costs of Political Pluralism: the Dilemmas of Difference and Equality in Arendt's "Reflections on Little Rock", in May and Kohn (eds.), Hannah Arendt: Twenty Years Later, p. 60 .

86 Arendt, Eichmann in Jerusalem, pp. 255-6. Also, Canovan, 'Friendship, Truth and Politics', p. 194.

87 Bohman, 'The Moral Costs of Political Pluralism', pp. 53 and 58. 
A richer version of toleration, an emphasis on access to the political world, an Arendtian sensibility about the nature of politics, a resistance to repressive violence and an active valuing of diversity can generate important political consequences in international society. These are as good reasons as human rights for intervention in the face of grave human suffering, for example, because they encompass and value the discourse of human rights. However, this Arendtian justification may be more politically acceptable because it does not privilege an abstract justification incompatible with other important versions of the moral agency of human beings. An Arendtian approach deepens and enriches concerns that liberals share over the nonreciprocity of toleration, taking what in many ways is a distinctly liberal argument and situating it in a discourse that is essential to meaningfulness and a sense of reality in human affairs. It thus addresses the problematic, abstract nature of human rights and other universal principles prominent in contemporary solidarism.

Arendt helps us take more seriously the politics of the 'humanitarian' part of humanitarian intervention. The apolitical, charitable, neutral and impartial idea associated with the Red Cross, often assumed in many discussions of humanitarian intervention, is not conceptually all-encompassing. Being human, and therefore the potential for humanitarianism, is about creating access to political space via engagement with and opening oneself to diversity. An unpredictability about politics and the outcomes of action makes institutional blueprints inappropriate. No 'onesize-fits-all' policy of humanitarian intervention is suitable for situations as different as Kosovo, Chechnya and Rwanda, for example. Universal requirements for political access, respect for community and toleration of diversity enable lines to be drawn in the sand, though. International society contributes to this via specific understandings of territorial borders and principles such as the non-use of force except in selfdefence, territorial integrity and non-intervention. These should be overridden when state authorities - those charged with respecting diversity internationally and granted rights and privileges domestically by membership of international society - or those aspiring to state authority, systematically and violently deny a community access to political space or attempt its eradication. This threatens international peace and security-order in international society - and the basis, even the possibility, of properly human politics that values, protects, respects and engages with diversity; that tolerates diversity and makes toleration a political virtue.

Addressing intolerance, including but not limited to intervention, must not itself be intolerant. Restoring access to political space, including restoring international peace and security, is the goal, not prescribing forms and institutions for an open political space. This access should include access to international society, establishing channels between individuals, communities and the international system. The need for intervention is a sign of international society's failure. Efforts to address such situations should not stop at the territorial borders of the state or states intervened into, but should evolve international society as part of an orderly system in conditions of anarchy and diversity. This is not to reify or embalm international society, isolating it from political crises within it. Its existence contributes to these crises, and their management, and above all their resolution, challenges international society's effectiveness and responsiveness. Thus prudence, circumspection and a concern to incorporate into putative rights of humanitarian intervention some of the classic limiting principles of the Just War tradition-proportionality, last resort, legitimate authority, reasonable prospects of success-are important because they 
protect international society. ${ }^{88}$ However, when circumstances require and enable the building of a more tolerant and human politics in diversity then these principles should be reconsidered and occasionally put aside, returning them to a worldly and engaged politics. Territorial borders, as features of international society, are thus ethically contingent, but not against cosmopolitan standards such as human rights, but against their contribution to a tolerant worldly politics of diversity where the politically mute but otherwise loud voice of violence is heard less often.

The power and persuasiveness of a constructivist English School theory to reinvigorate a solidarist agenda has shifted the School's ethical focus. The opportunity to move away from a 'second best' position - that an international society is the best that can be hoped for until anarchy and diversity can be overcome as blockages to a world society - must be fully explored. Yet, abandoning the pluralist ethical agenda may be premature. In relation to territorial borders, and possibly other 'pluralist' features of the international system, an ethic of toleration offers a fruitful line of enquiry.

\section{Conclusion-toleration and the English School}

This account of the status of territorial borders and of their potential to act as part of a system of toleration in international society, although of an Arendtian rather than liberal kind, has hinted at the depth of issues surrounding this question. Treating borders as constitutive rules and thus as live political questions, particularly via a constructivist methodological turn, has posed some difficult ethical questions. A more wide-ranging treatment of the issue of borders than is possible here would surely throw up equally difficult questions in relation to a number of other issues. This article has tried to make an argument that there may be good ethical reasons for granting weight to territorial borders and the kinds of rules and principles of international society that cluster around them. However, this does require a substantial shift in the way in which those arguments have traditionally been made. There is a need to focus on order in diversity as being equally important as order in anarchy. Equally, it also requires a revitalised pluralist ethical agenda within the English School, but not one that treats states as being the automatic manifestations of community. The growing diversity of the agenda and actors of international relations, in terms of both policy and theory, has made assumptions about states as homogeneous communities unsustainable. ${ }^{89}$ There is a need within pluralism as well as solidarism to consider the victims of power, not just its holders, and to open the channel between 'domestic' politics and international society.

Achieving, or even approximating, this task of offering a positive defence of territorial borders requires a more focused approach, stressing toleration and the role of territorial borders as restraints on the use of force. Classical English School theory sees this restraint as operating at the level of interstate relations as a way of protecting states from the imposition of external despotism. Hence the emphasis on

88 Wheeler, Saving Strangers, ch. 2.

89 John Williams, 'The Ethics of Borders and the Borders of Ethics: International Society and Rights and Duties of Special Beneficence', Global Society, 13:4 (1999). 
legitimate force as being in self-defence and the duty of states to ensure the perpetuation of international society itself.

However, this risks granting too free a licence to internal repression. It is this danger that causes constructivist English School approaches to see an opportunity to refocus the ethical agenda on solidarism. This substantially reduces the ethical status of territorial borders to being prudential or circumstantial, derivative from superior cosmopolitan ethical principles, although they remain important in practice and via their role in generating order amongst states.

This article has tried to suggest that territorial borders, via an idea of toleration, can be useful at both levels. Territorial borders and the rules clustering around them can continue to restrain drives to universal empire or other external despotism whilst also serving a function in resisting internal repression. With a concentration on restraining violence, and recast in terms of toleration as discussed here, the ethics of territorial borders can be refined. If non-reciprocity of toleration is intolerable, this sanctions a limited weakening of the non-intervention principle that is so tied up with territorial borders. Borders ought to be respected in the interests of toleration up to the point that activities within those borders cross the non-reciprocity line. Then outsiders may have the right to intervene to restore reciprocity, particularly if the armed force of the state is being used. This adds to the idea of threats to international peace and security providing a justification for intervention but without wholesale removal of the non-intervention principle. It also removes the need to redefine or interpret the international peace and security formula in ever more inventive ways. The ethos here is not of borders being used to protect or enshrine a right to cultural closure, as is arguably the position of Walzer, but instead is about borders helping to protect the right to participate in politics and to be tolerated in the full meaning of that term. ${ }^{90}$

An appeal to the importance of diversity and plurality of community membership enables us to downplay the centrality of territorial borders but without wiping out their significance and ethical importance. The role of international society is more concentrated upon restricting the tendency of states to use their claims to the monopoly of military might to crush diversity and display intolerance. This marks a move away from classical English School thinking which emphasises the need to protect the state; instead, international society ought also to be about protecting non-state based communities from the intolerance of states and their dominant political elites.

Toleration thus gives us a reason to respect the rules, norms and principles of international society, but also a reason to limit its importance. It is partially constitutive of a desirable diversity of human societies and because it offers the potential operational principle of toleration in the conduct of states that both contribute to and threaten diversity. This form of toleration, based on the approach to politics of Arendt, argues for reciprocal toleration in an open, pluralistic and popular politics rooted in the lived experience, in all its diversity, of people. This is seen as being the only way to produce and reproduce community and meaning, and to act in a properly political manner. International society has the potential to frame

90 Michael Walzer, Spheres of Justice: A Defence of Pluralism and Equality (Oxford: Martin Robertson, 1983). 
such a politics in the realm of interstate relations and to protect toleration by helping us identify the intolerant and by retaining the coercive force occasionally necessary to resist the intolerant.

International society has the potential to be the framing arrangements that act as an arena of compromise in international relations attracting, as Bull and Watson's definition points out, a recognition of the common interest in its maintenance, but which does not require a commitment to particular policies. ${ }^{91}$ Instead there is a commitment, 'to the rules and institutions that make public freedom possible as well as the limits on political power that allow for plurality'. ${ }^{92}$

A defence of international society does not have to result in conservatism and a defence of sovereignty, non-intervention and the rights of states over the rights of people and peoples. The potential for a transformative pluralist project in English School theory is immanent without having to declare that such can only spring from the solidarist wing. If we value diversity and recognise its importance, then it is possible that a politics of toleration, framed by international society, offers a vibrant normative agenda which respects and protects that diversity of history, community, and understanding of the world that helps us know who, as well as what, we are. Potentially available is a politics of responsiveness to diverse others via an incessant discourse about how to understand and to act in the world that we have so largely created. It can enable us to protect it from intolerance, violent repression and a denial of the role of difference in creating meaning for human life.

91 'By an international society we mean a group of states (or, more generally, a group of independent political communities) which not merely form a system, in the sense that the behaviour of each is a necessary factor in the calculations of the others, but also have established by dialogue and consent common rules and institutions for the conduct of their relations, and recognize their common interest in maintaining these arrangements'. Bull and Watson (eds.), The Expansion of International Society, p. 1.

92 Bohman, 'The Moral Costs of Political Pluralism', p. 68. 